\title{
Hybrid Upflow-Anaerobic Filter (HU-AF) Integrated technology for bio-methane generation from vinasse with shorter hydraulic retention time
}

\author{
Nani Harihastuti*, Rustiana Yuliasni, Silvy Djayanti, Novarina Irnaning H, Rame Rame, \\ Adi Prasetio \\ Centre of Industrial Pollution Prevention Technology, Semarang, Central Java, Indonesia
}

\begin{abstract}
Research about Hybrid Upflow-Anaerobic Filter (HU-AF) integrated technology for bioenergy generation from vinasse was conducted. Modification of influent flow system, expansion of filter contact area and addition of gas accumulator for biogas collection were used to enhance the degree of vinasse biodegradation biogas generation, and yet to shorten the hydraulic retention time (HRT). Hybrid Upflow-Anaerobic Filter (HU-AF) integrated technology was a double dome reactor with sequential connection, with up-flow inlet distribution inside the reactor. Total volume of HU-AF was $60 \mathrm{~m}^{3}$. A mixing and a feeding chamber, with volume $3 \mathrm{~m}^{3}$, each were installed before $\mathrm{HU}-\mathrm{AF}$ reactor. A reservoir chamber with volume of $6 \mathrm{~m}^{3}$ was added after $\mathrm{HU}-\mathrm{AF}$ reactor. OLR was $2.04 \mathrm{~kg} \mathrm{COD} /$ day. A methanogenic seed sludge derived from anaerobic lagoon. The experiment was carried out initially by seeding, acclimatization and adaptation of microorganisms inside the reactor. A feeding ratio of vinasse: water $=1: 4$, and initial $\mathrm{pH}$ of 6 were adjusted. Result showed that Full-scale HU-AF integrated technology was able to degrade COD with maximum degradation of COD $55.45 \%$ at $\mathrm{pH} 7.1$, and shorten the HRT into 32 days. Biogas production was consisted of $57.21 \%$ methane, $13.98 \% \mathrm{CO}_{2}$ and various gases $28.1 \%\left(\mathrm{H}_{2} \mathrm{~S}, \mathrm{VOC}, \mathrm{CO}\right.$ and $\left.\mathrm{H}_{2} \mathrm{O}\right)$. This experiment showed that HRT was shorter than conventional reactor.
\end{abstract}

Keywords. ethanol industry, vinasse wastewater, bioenergi, Hybrid Upflow-Anaerobic Filter, methane generation

\section{Introduction}

In 2020-2030, Indonesia is predicted facing energy crisis[1]. Industrial sector, which mainly depended to fossil fuel, was the one who mostly impacted. There is an urgency to find an alternative renewable energy to fossil fuel.

\footnotetext{
*Corresponding author: nnharihastuti@gmail.com
} 
Perpres No.5/2006 National Energy Policy have set National Energy Management for developing mix primer energy in 2025, where $23 \%$ national energy come from renewable sources, particularly $8.3 \%$ derived from bioenergy. Bioenergy potential could be from forest timber, crops, palm oil, pulp and paper, starch industrial waste etc.

Ethanol industry is one of industry that based on molasses as raw materials. Beside ethanol as main product, vinasse and stillage are considered to be by products of fermentation and distillation process. Vinasse has characteristic of high organic, acidic $\mathrm{pH}$, high temperature and high volume. Vinasse is considered to be bioenergy source that yet to be explored immensely[2]. The issue related to vinasse is aquatic pollution, that come from poor management of wastewater. Vinasse has pollutant concentration as follows: $\mathrm{BOD}_{5}=109.038$ $\mathrm{mg} / \mathrm{l}, \mathrm{COD}=353.797 \mathrm{mg} / \mathrm{l}$ and $\mathrm{TSS}=7,200 \mathrm{mg} / \mathrm{l}, \mathrm{pH} 4-5$ and temperature $40-50^{\circ} \mathrm{C}[2]$. Regarding to that, vinasse has large potential to be utilized as raw material for biogas/bioenergy. Every $1 \mathrm{~kg}$ COD removal will generate 200-350 liter methane[3].

Technology to convert high organic waste into biogas still depend on anaerobic conventional technology[4]. Bottlenecks of anaerobic conventional technology are long retention time, spacious, and low methane generation. Furthermore, even though Hybrid Anaerobic Baffle Reactor (HABR) could remove COD up to $92 \%$, but this technology still require long retention time[5]. Another example is Up-flow Anaerobic Sludge Blanket (UASB) which converts COD $>86 \mathrm{~kg} \mathrm{COD} / \mathrm{m}^{3}$. days, with removal efficiency of $60 \%$ but retention time is unknown.

One of ethanol industries that have utilized its wastewater is PT. Indo Acidatama, located in Karanganyar-Solo. PT. Indo Acidatama has utilized vinasse, convert it into biogas energy using four units anaerobic facultative chambers, with total volume of $120,000 \mathrm{~m}^{3}$. The chambers were covered by polymer HDPE, and have total retention time of 40-50 days. This technology has weakness, such as spacious, long HRT, dangerous gas leakage, less biogas production etc. PT Madu Baru that is located in Yogyakarta, have not used its wastewater as bioenergy source but has converted half of its wastewater into liquid fertilizer, and treated the rest in wastewater treatment plant (using conventional anerobic-aerobic technology). PT Enero, one of ethanol industry located in Mojokerto, East Java, still use conventional technology with HRT 88 days. PT Enero use two SS vertical tanks with agitation, with total volume of 30.000 liters. However, biogas is not utilized yet.

As already described, based on its characteristic, vinasse has high potential for biogas production. For $1 \mathrm{~kg}$ COD reduction will produce 200-350 liters' methane. Assume that vinasse wastewater volume is $307,045 \mathrm{~m}^{3} /$ days, and $75 \%$ COD removed, with conversion factor of $4.500-6.300 \mathrm{kcal} / \mathrm{m}^{3}$ calories per $\mathrm{m}^{3}$ wastewater. The total amount of biogas generation will be $1.381 .703-1.934 .383,5 \mathrm{kcal} /$ days. If average energy need for ethanol distillation process is $2700 \mathrm{kcal} / \mathrm{L}$, biogas production could be used to produce $511.7-716.4$ $\mathrm{m}^{3} /$ days. This scheme can be applied in alcohol small industrial center in Sukoharjo that still use woods as energy sources.

This research focus on innovative reactor model for high organic wastewater conversion into biogas namely Hybrid Upflow-Anaerobic Filter (HU-AF) that could shorten hydraulic retention time to 20 -25 days. HU-AF reactors models use filters and up-flow inlet feeding to expand contact area between substrates and microorganisms. 


\section{Material and Method}

\subsection{Reactor Set up}

\subsubsection{Lab scale}

BMP (Bio-methanation Potential Test) test was conducted to analyze the degree of COD degradation, in line with methane generation. Referred to method that was developed by [6] (Figure 1). Table 1 shows vinasse initial inlet characterization.

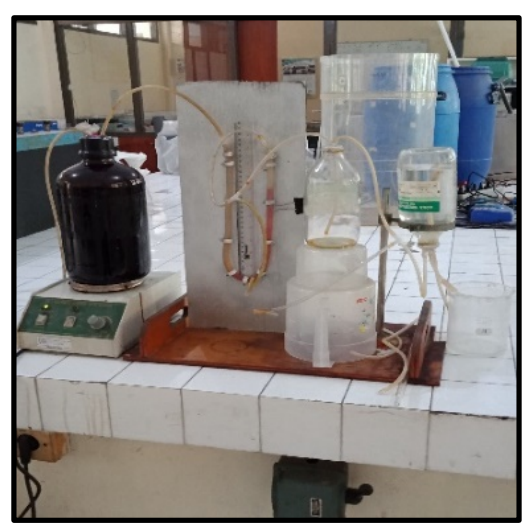

Figure 1. BMP test analyzer

Table 1. Vinasse initial inlet parameter concentration

\begin{tabular}{|l|l|c|c|}
\hline No. & \multicolumn{1}{|c|}{ Parameter } & Concentration & Units \\
\hline 1. & BOD & 92,045 & $\mathrm{mg} / 1$ \\
\hline 2. & COD & 261,206 & $\mathrm{mg} / 1$ \\
\hline 3. & TSS & 32,450 & $\mathrm{mg} / 1$ \\
\hline 4. & Total N & 793.8 & $\mathrm{mg} / 1$ \\
\hline 5. & Total P & 35.25 & $\mathrm{mg} / 1$ \\
\hline 6. & Sulfida $\left(\mathrm{sbg} \mathrm{S}^{-2}\right)$ & 18.25 & $\mathrm{mg} / 1$ \\
\hline 7. & Sulfat $\left(\mathrm{SO}^{-2}\right)$ & 2,026 & $\mathrm{mg} / 1$ \\
\hline 8. & MLSS & 91,900 & $\mathrm{mg} / 1$ \\
\hline 9. & MLVSS & 10,850 & $\mathrm{mg} / 1$ \\
\hline 10. & pH & 4.7 & - \\
\hline 11. & Temperature & 55 & ${ }^{\circ} \mathrm{C}$ \\
\hline
\end{tabular}




\subsubsection{Full-scale application}

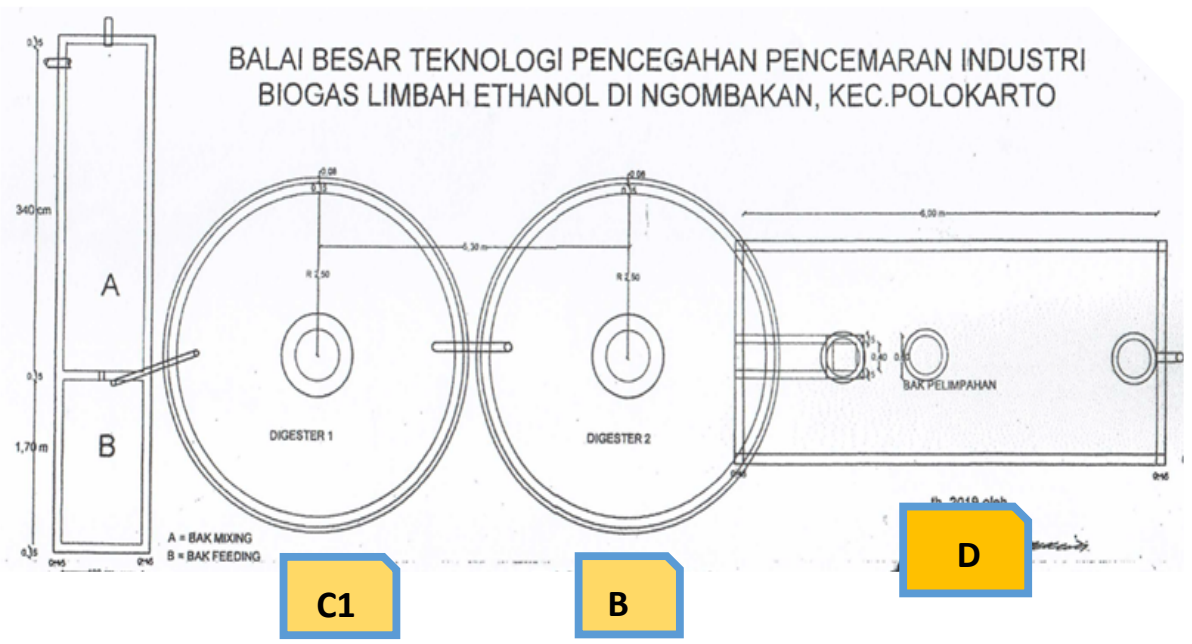

Figure 2. Full scale HU-AF reactor lay-out

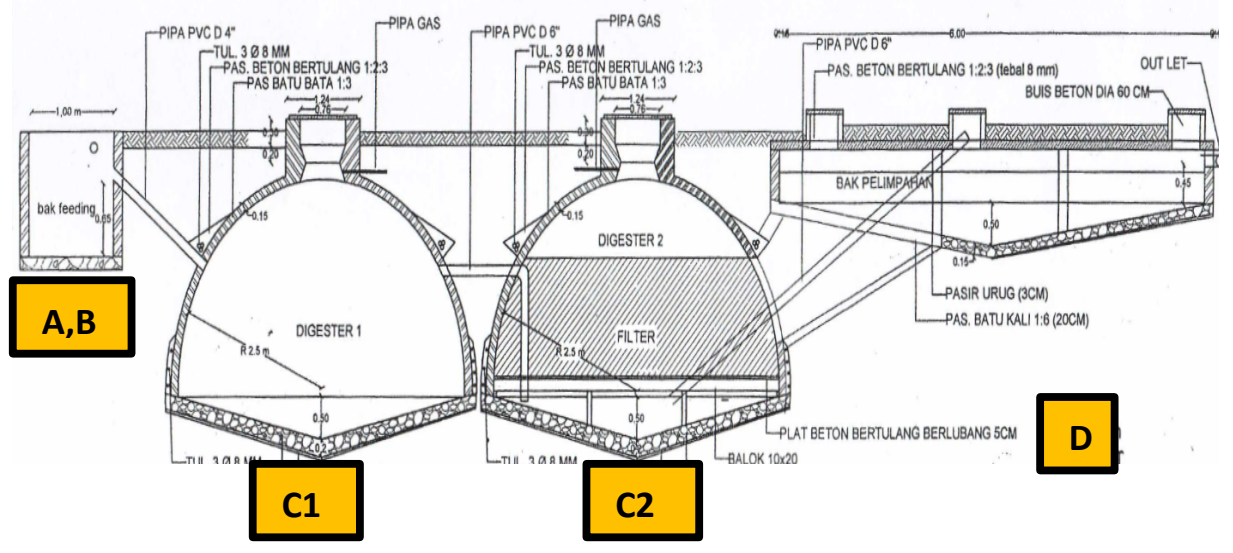

Figure 3. HU-AF reactor details

Legends:

A : Mixing chamber

B : Feeding Chamber

C1 : Dome 1 (without filter)

C2 : Dome 2 (with filters)

D : Reservoir chamber

Hybrid Upflow-Anaerobic Filter (HU-AF) integrated technology contained of double dome reactors $(\mathbf{C 1}$ and $\mathbf{C 2}$ ) with sequential connection, with up-flow inlet distribution inside the reactor. Total volume of HU-AF was $60 \mathrm{~m}^{3}$. A mixing (A) and a feeding chamber (B), with volume $3 \mathrm{~m}^{3}$, each were installed before HU-AF reactor. A reservoir chamber (D) with volume of $6 \mathrm{~m}^{3}$ was added after HU-AF reactor. 


\subsection{Material}

For both lab and full scale application:

Vinasse with initial characteristic written in table 1 was used. For feeding, vinasse was diluted by water in the ratio of 1: $4=$ vinasse: water (final concentration is shown in table 2). Lime $(\mathrm{CaO}$, technical grade) with concentration of $210 \mathrm{ml} \mathrm{CaO}$ per $\mathrm{L}$ vinasse was used to adjust the $\mathrm{pH}$ from initial $\mathrm{ph}$ of 3.6 to 6.0. Urea and TSP (technical grade) was added in the ratio of BOD: $\mathrm{N}: \mathrm{P}=100: 2.5: 0.1$ [7]. Macro and micronutrients, referred to [8] and [9] were added. For microorganisms seed, sludge derived from anaerobic lagoon WWTP was used.

Table 2. Characteristic inlet after dilution (vinasse: water $=1: 4$ ratio)

\begin{tabular}{|c|c|c|c|}
\hline No. & Parameter & unit & Concentration \\
\hline 1 & $\mathrm{pH}$ & - & 6.3 \\
\hline & COD & $\mathrm{mg} / \mathrm{L}$ & 34468 \\
\hline 3 & BOD & $\mathrm{mg} / \mathrm{L}$ & 10459 \\
\hline 4 & MLSS & $\mathrm{mg} / \mathrm{L}$ & 2830 \\
\hline 5 & MLVSS & $\mathrm{mg} / \mathrm{L}$ & 710 \\
\hline 6 & Total P & $\mathrm{mg} / \mathrm{L}$ & 0.105 \\
\hline 7 & Total N & $\mathrm{mg} / \mathrm{L}$ & 453.6 \\
\hline 8 & Sulfide & $\mathrm{mg} / \mathrm{L}$ & 39.7 \\
\hline 9 & Sulfate & $\mathrm{mg} / \mathrm{L}$ & $<0.26$ \\
\hline 10 & Nitrate & $\mathrm{mg} / \mathrm{L}$ & 2.473 \\
\hline 11 & Nitrite & $\mathrm{mg} / \mathrm{L}$ & $<0.001$ \\
\hline
\end{tabular}

\subsection{Operational Condition}

- Lab-scale application (Bio-methanation Potential test)

BMP test was conducted in batch, with volume reactor was $5 \mathrm{~L}$ and run for 50 days. Periodically (every 2 or 3 days) COD and $\mathrm{pH}$ were collected and analyzed.

- Full-scale application

Seeding was done through adding sludge seed derived from anaerobic lagoon WWTP alcohol industry, with volume $20 \%$ from total reactor volume (around $6 \mathrm{~m}^{3}$ each dome). Nutrients (macro, micronutrients urea and TSP) were added and reactor was left for 7 days. After 7 days, reactor was fed with vinasse wastewater with 4 times dilution and $\mathrm{pH} 6$ until it was full, then left from another 7 days. Afterwards, reactor was fed daily with vinasse wastewater (with flow rate $1.5 \mathrm{~m}^{3} /$ day) and running for 34 days. $\mathrm{COD}$, $\mathrm{pH}$ and gases $\left(\mathrm{CH}_{4}, \mathrm{CO}_{2}\right)$ were analyzed.

\subsection{Analysis}

Gases were measured using Gas Chromatography and COD, BOD, TSS, $\mathrm{pH}$, temperature, MLSS, MLVSS, N total, $\mathrm{P}$ total, Sulfate $\left(\mathrm{SO}_{4}^{-}\right)$, alkalinity, nitrite, nitrate, Total Plate Count (TPC) and sulfide were analyzed using APHA AWWA. 


\section{Result and discussion}

\subsection{Lab scale}

BMP test (bio-methanation potential test) was conducted to know the maximum anaerobic organic degradation, which theoretically in line with potential methane production. In BMP test, two different substrates were used, Diluted inlet vinasse wastewater (4 times diluted with water) and non-diluted inlet vinasse wastewater. Diluted inlet had initial COD 38499 $\mathrm{mg} / \mathrm{L}(\mathrm{OLR}=0.19 \mathrm{~kg} \mathrm{COD} /$ day $)$ and non-diluted had COD 168,516 mg/L $(\mathrm{OLR}=0.8 \mathrm{~kg}$ $\mathrm{COD} /$ day).

Figure 4 shows organic degradation profile of both diluted and non-diluted substrate. Organic degradation was indicated by COD reduction during 50 days of BMP test. For nondiluted substrate, initial COD was $168,516 \mathrm{mg} / \mathrm{L}$. COD was decreased to $113,844 \mathrm{mg} / \mathrm{L}$ after 27 days, and was stagnant. The maximum COD removal of non-diluted substrate was $33.52 \%$ (figure 5). On the other hand, diluted substrate with initial COD of $38,499 \mathrm{mg} / \mathrm{L}$ could reduce COD value into $13,213 \mathrm{mg} / \mathrm{L}$ and had maximum organic degradation of $65.68 \%$ with HRT of 21 days (figure 5). Low organic degradation in non-diluted substrate was might be because of accumulation of VFA (volatile fatty acid) such as propionate acetate, butyrate that accumulated in the system. The accumulation of VFA made the $\mathrm{pH}$ in the system drop to below 6.0 (Figure 5) and turn to be slightly acidic. The accumulation of VFA and pH drop made the system unbalance, that made acidogenesis microorganisms dominant in the system and inhibit the growth of methanogens microorganisms. Methanogens growth were strictly correlated with $\mathrm{pH}$, with optimum $\mathrm{pH}$ growth was $6.5-7.5$ [10]. In contrary, figure 5 also shows that $\mathrm{pH}$ in diluted substrate system increased from 5.8 to 7.6, indication of balanced system in anaerobic condition. Thus the organic degradation could get a maximum value of $65.68 \%$.

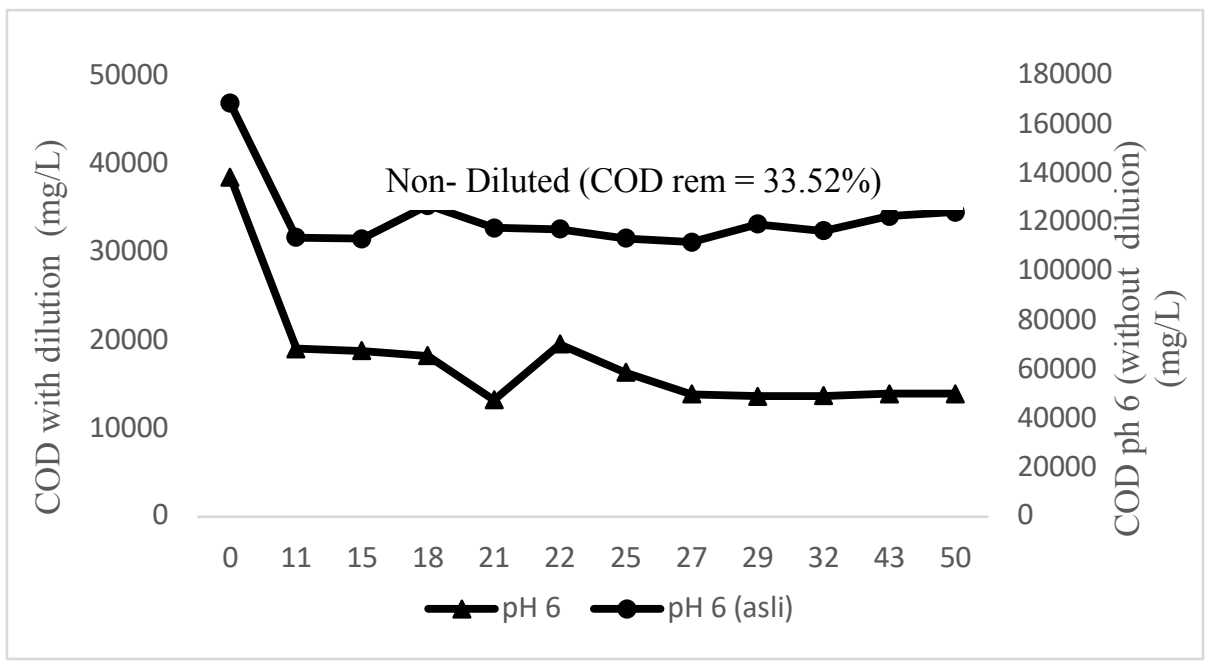

Figure 4. COD reduction profile during 50 days BMP test

Diluted $(\mathrm{COD}$ rem $=65.68 \%)$ 


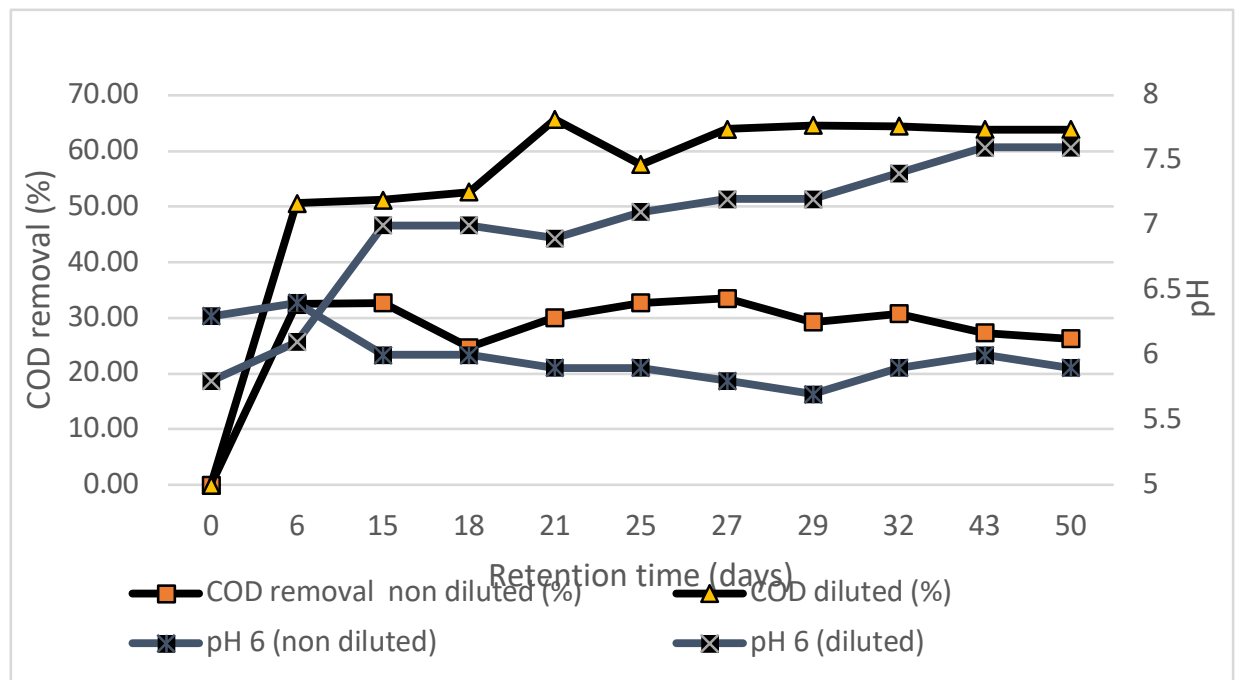

Figure 5. COD removal vs $\mathrm{pH}$ profile during BMP test from 2 different substrates, diluted and nondiluted substrates.

\subsection{Full-scale application}

Results from BMP test was then used as a basis for full scale application. Full scale application was taking place in traditional small scale industry, in Polokerto, Sukoharjo Central Java. The operational condition was divided into 3, namely seeding, acclimatization, and continuous running. Seeding was done by adding $20 \%$ sludge seed into the reactor (around $12 \mathrm{~m}^{3}$ total for 2 domes). Urea, phosphate, Macro and micronutrients were added, then reactor was left for 7 days. Acclimatization was done by filling the reactor to full with mixing of water and vinasse wastewater at the ratio 4:1. $\mathrm{pH}$ was adjusted to 6 using $\mathrm{CaO}$. Afterwards, reactor was left for another 7 days. During seven days period, gas production was monitored using manometer that was attached to the reactor. When gas formation was indicated, continuous run was started. The total daily flowrate for vinasse wastewater was $1.5 \mathrm{~m}^{3} /$ day. The daily feeding was divided into 3 times period; each was $0.5 \mathrm{~m}^{3}$ using submersible pump. Continues running was done by mixing $0.5 \mathrm{~m}^{3}$ vinasse with $\mathrm{CaO}$ to achieve $\mathrm{pH} 6$, in mixing chamber. Afterward, vinasse wastewater was flown to the feeding chamber and pumped into the reactor, and was done three times a day. OLR was $2.04 \mathrm{~kg}$ $\mathrm{COD} /$ day. The continuous running was run for 34 days. Figure 6 showed COD reduction and COD removal profile during continuous running.

Figure 6 shows that maximum COD reduction occurred at days 34 with maximum COD reduction from $34,468 \mathrm{mg} / \mathrm{L}$ to $15,355 \mathrm{mg} / \mathrm{L}$ (55.54\%). This result was lower than BMP test result, due to indication of leakage inside the reactor. Figure 7 shows that maximum methane production was $57.21 \%$ and $\mathrm{CO} 213.98 \%$, achieved at day 33 . Figure 7 also shows that $\mathrm{COD}$ removal, methane and $\mathrm{CO}_{2}$ generation were correlated with $\mathrm{pH}$. Methane generation and $\mathrm{COD}$ removal increased when $\mathrm{pH}$ rise from 6.3 to 7.1. In contrary, the $\mathrm{CO}_{2}$ production decreased as $\mathrm{pH}$ increased. This is a normal phenomenon in anaerobic biodegradation pathway using mix cultures microorganisms. Anaerobic biodegradation has 4 stages, namely hydrolysis, acidogenesis, acetogenesis, and methanoganesis[11]. High concentration of $\mathrm{CO}_{2}$ with $\mathrm{pH}<6.5$ indicate that stage is still in the acidogenesis/fermentation phase. Normally in acidogenesis/fermentation stage, VFA (propionate, acetate, butyrate), $\mathrm{H}_{2}$ and $\mathrm{CO}_{2}$ are generated. $\mathrm{pH}$ was also slightly acidic because the production of VFA (at $\mathrm{pH}$ around $5.5-$ 6.5). To obtain the maximum methane production, the production of acetate should be 


\section{ICENIS 2020}

maximized. VFA must be oxidized to acetate and $\mathrm{H}_{2} / \mathrm{CO}_{2}$ also have to be synthesized to form acetate by homoacetogen. This stage is known by acetogenic phase. The increased in $\mathrm{pH}$ to 7.1 indicate of the release of some alkalinity in the system to buffer the $\mathrm{pH}$, thus able to balance condition. The condition favors the growth of homoacetogen and methanogens. Acetate was optimally produced then consumed to form methane.

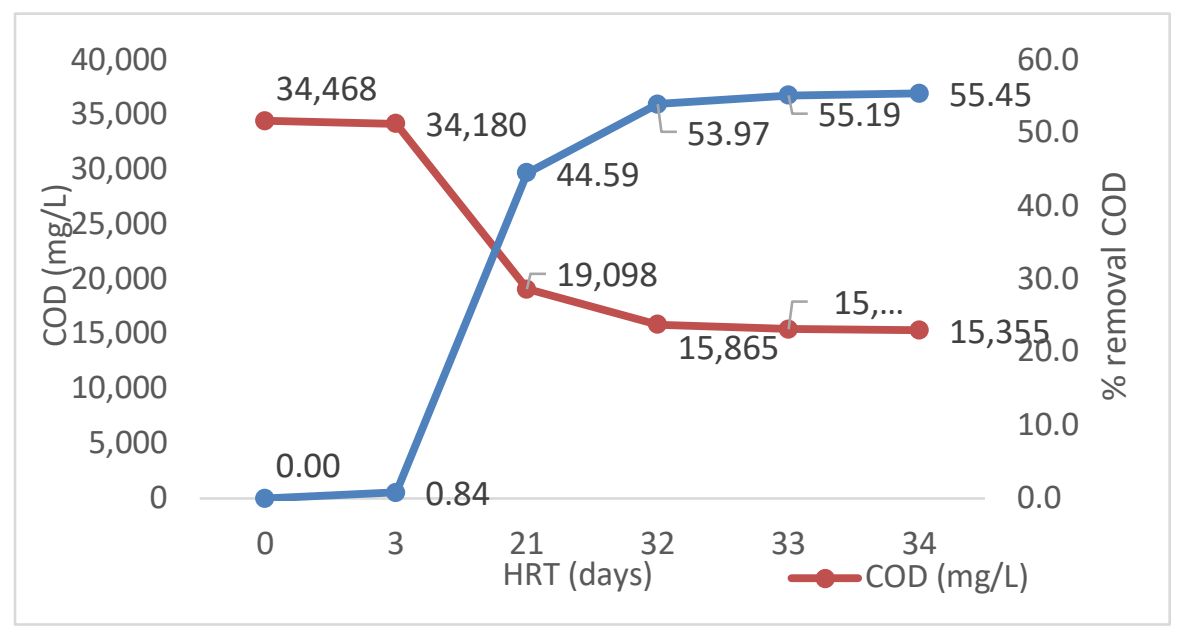

Figure 6. COD degradation and COD removal through period of experiment

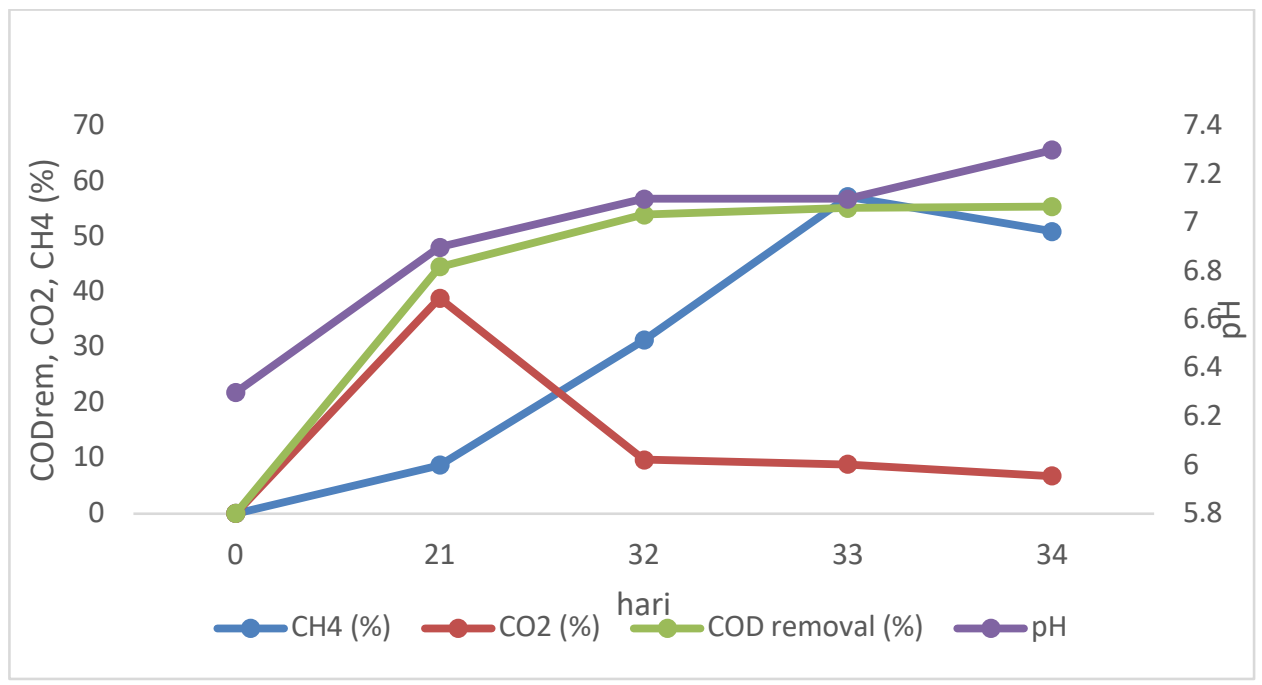

Figure 7. Correlation between $\mathrm{CH}_{4}, \mathrm{CO}_{2}$ production, and $\mathrm{COD}$ removal with $\mathrm{pH}$

\section{Conclusion}

BMP test showed that to get the maximum organic degradation/removal, vinasse wastewater must to be diluted. Four times dilution, make organic degradation increased from $33.52 \%$ to $65.68 \%$. BMP test acted as a basis for full scale application. Full scale application of methane production from vinasse was using Upflow-Anaerobic Filter (HU-AF) Integrated technology with total volume of $60 \mathrm{~m}^{3}$. Full scale application showed that maximum COD degradation occurred at days 33 when $\mathrm{pH}$ increased from 6.3 to 7.1 . Methane production was $57.21 \%$ and 
CO2 13,98\%, the experiment showed that Hybrid Upflow-Anaerobic Filter (HU-AF) Integrated technology is able to shorten the HRT to 33 days with maximum methane generation $57.21 \%$.

\section{Acknowledgement}

This experiment was supported by Centre of Industrial Pollution Prevention Technology, The Ministry of Industry, Semarang. Authors also thank to Saifuddin for the laboratory experiment assistance.

\section{Reference}

[1] A. Hidayat, "Pada 2020-2030, Indonesia Terancam Krisis Energi," Tempo.co, (2016).

[2] N. Harihastuti and B. Marlena, "Bioenergy Potential Based on Vinasse from Ethanol Industrial Waste to Green Energy Sustainability," E3S Web Conf., vol. 31, pp. 20172019, February, (2018).

[3] C. Polprasert, Organic waste recycling: technology and management. IWA Publishing, (2007).

[4] M. S. Chauhan and A. K. Dikshit, "Indian Distillery Industry: Problems and Prospects of Decolourisation of Spentwash," Int. Conf. Futur. Environ. Energy, vol. 28, pp. 119123, (2012).

[5] S. R. Lekshmi, "Treatment and Reuse of Distillery Wastewater," vol. 4, no. 4, pp. 339344, (2013).

[6] G. Esposito, L. Frunzo, F. Liotta, A. Panico, and F. Pirozzi, "Bio-Methane Potential Tests To Measure The Biogas Production From The Digestion and Co-Digestion of Complex Organic Substrates," pp. 1-8, (2012).

[7] K. Möller and T. Müller, "Effects of anaerobic digestion on digestate nutrient availability and crop growth: A review," Eng. Life Sci., vol. 12, no. 3, pp. 242-257, (2012).

[8] M. Narra, V. Balasubramanian, A. Kurchania, B. Sen Pathak, and M. Shyam, "Enhanced biogas production from rice straw by selective micronutrients under solid state anaerobic digestion," Bioresour. Technol., vol. 220, pp. 666-671, (2016).

[9] L. Janke et al., "Optimization of semi-continuous anaerobic digestion of sugarcane straw co-digested with filter cake: Effects of macronutrients supplementation on conversion kinetics," Bioresour. Technol., vol. 245, pp. 35-43, (2017).

[10] N. Harihastuti, B. Marlena, N. H. Irnaning, and R. Yuliasni, "Decomposition process of stilage/vinasse organic compound from ethanol industry as renewable energy source," AIP Conf. Proc., vol. 2197, no. January, (2020).

[11] G. Esposito and L. Frunzo, "Anaerobic co-digestion of organic wastes . Rev Environ Sci Biotechnol Anaerobic co-digestion of organic wastes," no. June 2014, (2012). 